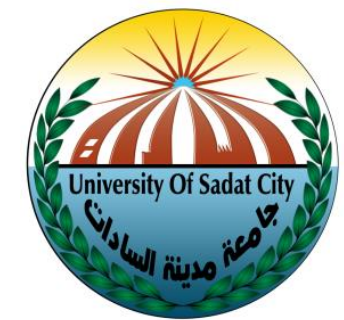

Faculty of Education

Department of Curriculum, Instruction \& Education Technology

\title{
The Effectiveness of a Program Based on English Digital Storytelling in Developing Some Critical Reading Skills for Preparatory Students
}

A thesis submitted in partial fulfillment of the requirements for Master Degree (Curriculum \& Instruction of EFL)

\author{
Submitted by \\ Ayman Ahmed Mahmoud Abdel-Khalek \\ EFL teacher
}

\author{
Supervised by

\section{Prof / Adel Tawfik Ibrahim} \\ Professor of Curriculum \& Instruction \\ and Dean of Faculty of Education \\ University of Sadat City

\section{Prof / Gamal Mohamed Shehata} \\ Professor emeritus of curriculum \&Instruction \\ EFL Methodology \\ Minia University
}




\section{Introduction:}

English language has come to occupy a very important position nowadays in many circles and on many levels. Firstly; it has become the official language in fields of science, technology, tourism and international scientific publications. Secondly; according to W3 Techs, a specialized institution in web technology surveys, more than $55 \%$ of the internet websites content is in English. Finally; English is the dominant language in the world of business and trade as well as being the official language used in international organizations and at international conferences. Therefore, teaching/ learning English as a foreign language has turned to be a must in the modern times in order to successfully communicate with the world.

Teaching English as a foreign language (EFL) aims at acquiring and developing four main skills namely; listening, speaking, reading and writing. However, the receptive skills; listening and reading, are of major effect in language acquisition and learning as they are means to increase students' input of the target language. In the same vein, reading has always received more focus, in Egypt, as it receives more focus in EFL achievement exams. In addition, Akin, F.; Koray, O. and Tavukçu, K. (2014, 2445) see reading as the main way of acquiring information and it is the pre-requisite for individual success in all walks of life. Similarly, Medina, S. $(2012,81)$ states that in many instances around the world we may argue that reading is the most important foreign skill. For Demiroz, H. $(2007,67)$ it is also an inevitable skill of life, which caused the existence of a great accumulation of information.

In The National Curriculum Framework for EFL Grades 1-12, issued by the Egyptian Ministry of Education (2012, pp 56 - 57), preparatory EFL learners are expected to use critical reading strategies in the EFL curricula. Standard 5 in the document reads: "Learners practice higher level thinking skills while reading". One of the outcomes for first year preparatory EFL curriculum is stated as: "To differentiate between fact and opinion in grade appropriate narrative/expository texts". Yet, there is no single activity, throughout the curriculum, to cover this intended outcome. On the 
other hand, in the Strategic Plan of Pre-college Education 2014 - 2030 in Egypt (2014, 59), it was diagnosed that current curricula are static and do not cope with modern trends (in education) and their correlation with knowledge economy. They do not provide the student with enough opportunities to create, think critically or build intrinsic initiative (for learning) and respect it. It was found that assessment processes ignore critical thinking skills as well (p. 61). And developing critical thinking is claimed to be a major aim of any development of school and schooling in the future (p. 122).

That is why a lot of studies were directed to investigate critical and creative reading ; like Abu Zeid (2017); Bedeer (2017); Mohammed (2017); AbdulAal (2016); El Morsi (2015); Ismail (2015); Allam (2014), El-Embaby (2012); Mohamed (2012); El-lehleh (2011); El-Sakka (2011); Makhyoun (2008); Mohamed (2002) and Mohamed (1999).

Critical reading (CR) is important not only in academic milieu, but also important for life. For McLaughlin, M. and DeVoogd, G. (2004, 52) people need to read from a critical stance and to question rather than passively accept the information they encounter because when we were in school, we believed everything we read. Students never question who is writing the text, who is determining what topics would be included/ excluded. We rarely question if there is any perspective other than the one presented. That is why Zin, Z., Eng, W. and Rafik-Galea, Sh. $(2014,44)$ assure that critical reading is not only important for academic reasons, but it is also a toolkit to read the world. According to Paul, R \& Elder, L. ( 2014, 35), a critical person raises vital questions and problems, formulating them clearly and precisely; gathers and assesses relevant information, and effectively interprets it; comes to well-reasoned conclusions and solutions, testing them against relevant criteria and standards; thinks open-mindedly within alternative systems of thought, recognizing and assessing, as need be, their assumptions, implications, and practical consequences; and communicates effectively with others in figuring out solutions to complex problems. 
Because critical reading is essential for language learners, it received much attention in pedagogical literature. Zaki, E et al $(2014,4)$ assured that there is no more central issue

of education than thinking, it should be developed and integrated into the process of foreign language learning and teaching, in other words, learners should learn how to critically produce and receive information through language. Minakova, L. $(2014,324)$ proved that block-schemes allowed non-language-majoring students to understand the main ideas and to answer the questions more efficiently due to developing skills as analyzing, synthesizing and evaluating the material.

Since the 21 st century is often called the century of digital technology and information explosion, utilizing technology in education has become inevitable. The role of technology in education is to assist in the teaching process. As Marc Prensky $(2008,2)$ claims “Today's technology offers students all kinds of new, highly effective tools they can use to learn on their own'. Standley, M. $(2003,17)$ states that today, digital cameras, editing software and electronic media outlets allow more students than ever to tell their own stories more easily, and to share them more widely. According to Tamim, R. et al $(2011,2)$ the impact of the digital technologies and especially the Internet in the twenty-first century post-secondary classroom is unquestionable and dramatic. One of these modern technological tools is digital storytelling (DST).

\subsection{Digital Storytelling}

The movement of DST was introduced in the late 1980s with the efforts of Joe Lambert and Dana Atchley. They founded the Center for Digital Storytelling in Berkeley, California. They offered training to people interested in creating and sharing their narratives as stated in Robin, B. $(2008,222)$.

DST is simply defined in Ohler, J. $(2013,16)$ as the use of personal digital technology to combine a number of media into a coherent narrative. Digital stories in Education are typically driven by an academic goal, use low-end technology that is commonly available to students and usually are in the form of short (two to four 
minute) quasi movie that an audience watches via computer or any other digital means. A similar definition is in Robin, B. $(2016,18)$ who states that Digital Storytelling combines the art of telling stories with a mixture of digital media, including text, pictures, recorded audio narration, music and video. These multimedia elements are blended together using computer software, to tell a story that usually revolves around a specific theme or topic and often contains a particular point of view. Lisenbee, P. and Ford, C. $(2018,130)$ showed the modern tools used in DST. They state that DST uses technological tools such as an interactive whiteboard (IW), computer, cellular phone, or tablet. These technological tools provide a foundation for offering digital storytelling experiences in a classroom.

Marone, F. $(2017,972)$ adds that DST is characterized by adding the personal voice to images, titles, effects and transitions that run on the screen, at times accompanied by sounds or music that give rhythm to the narration. While $\mathrm{Xu}, \mathrm{Y}$., Park, H., \& Baek, Y. $(2011,181)$ define DST as the conducted use of digital technology as the medium or method of expression, in particular using digital media in a computer-network environment. For them, encompasses these key characteristics: Flexibility, universality, interactivity and community formation.

In literature, a successful DST has some general aspects. According to the Digital Storytelling Association, effective digital storytelling uses the multimedia components of narrative, text, images, and sound (e.g., music, narration). The concept of merging audio and graphics is also repeated in Normann, A. $(2011,1)$ and Ribeiro, S. (2015, 45) who see DST as a merger between the old storytelling tradition and the use of new technology emphasizing using graphics, audio, and video.

DST is different from usual videos or even video clips. DST makes use of videos as tools along with other media forms: e.g. pictures, sounds, transitions and animations; to convey a message. For Robin, B. $(2016,18)$ DST is different from videos in that DST contains a personal point of view, its content is not necessarily 
factual, its creator narrates it, and finally it is short. For Boase, C. $(2008,1)$ DST is short: up to two and a half minutes long only.

\subsection{The Merits of using DST in Instruction:}

DST has many advantages when used in Education. Smeda, N. $(2014,37)$ states that DST can facilitate a constructivist approach for teaching and learning. That conforms to Sweeney-Burt, N. $(2014,5)$ who asserts that DST represents a constructivist approach to learning, which recognizes the relationship between education and experience. In addition, DST is considered a means to active learning that is based on students' active participation as Barrett, H. $(2005,1)$ explains that DST facilitates the convergence of four student-centered learning strategies: student engagement, reflection for deep learning, project based learning, and the effective integration of technology into instruction. The following shape describes this convergence.

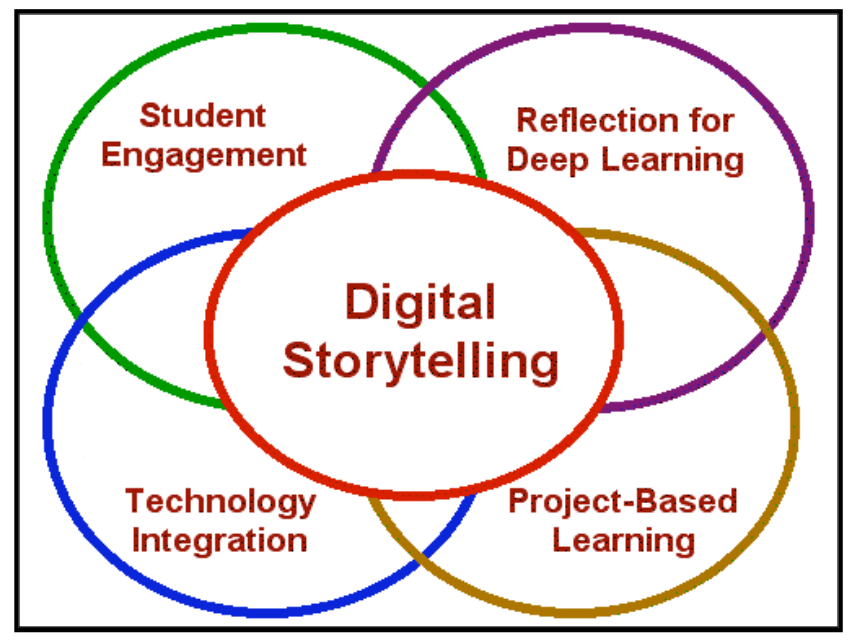

Fig (1): DST as a Convergence of Student-Centered Learning Strategies

In the same line, DST involves students and promotes their interaction. $\mathrm{Xu}, \mathrm{Y}$., Park, H., \& Baek, Y. (2011, 180) claim that entertainment-based learning environments can make learning contents more attractive, and thus can lead to 
learners' active participation and facilitate learning. Hussain, H. \& Shiratuddin, N. $(2015,42)$ add that meaningful digital stories inspire audiences to think and reflect upon the story being told. It is also beneficial in improving communication skills in Robin, B. $(2005,4)$ who believes that students who participate in the creation of digital stories may develop enhanced communications skills by learning to organize their ideas, ask questions, express opinions, and construct narratives. Hokanson, B.; Clinton, G. and Kaminski, K. (2018, pp 271, 272) point out that DST improves engagement, critical thinking, and creativity. It can also help educators engage students and facilitate meaningful learning.

In literature, the effect of DST was thoroughly investigated to verify its effect on different instructional areas. For example, Yee, B., Abdullah, T. and Nawi, A. (2017, 708) examined the effect of DST on prospective teachers training programs. The findings showed that DST enhanced understanding of pedagogical content knowledge, improved teaching practice and professional development when they use digital storytelling in classroom. While Xu, Y., Park, H., \& Baek, Y. $(2011,189)$ examined the effect of writing for digital storytelling on writing self-efficacy and on flow in a known as Second Life. They found out that DST in virtual learning environment is more effective than digital storytelling off-line. In the same line, Sharda, N. (2010) affirms that DST provides an educational milieu that supports communication, reflection, construction, and collaboration. He adds that DST helps students to explore, create, and evaluate their ideas both individually and collaboratively. In addition, DST is a literacy tool for Robin, B. $(2008,224)$ who sees that DST by students provides a strong foundation in many different types of literacy, such as information literacy, visual literacy, technology literacy and media literacy.

According to LoBello, Ch. $(2015,2)$ DST consolidates students' motivation, towards writing, students' self-perception, creativity, and overall writing performance. Alpysbayeva, D. $(2010,8)$ suggests integrating digital storytelling into the language curriculum as a creative language learning technique that can improve students' level 
of learning in reading, writing, speaking and listening. While Maddin, E. $(2011,1)$ recognizes DST as a motivating instructional approach that engages students in critical thinking and reflective learning. For Hung, C.-M., Hwang, G.-J., \& Huang, I. (2012, 370), DST presents a favorable effect on knowledge construction and motivation promotion.

More elaborative benefits are stated in Ming, Th. et al $(2014,490)$ who confirm that DST assists in the development of effective communication skills and experiences in specific areas such as: Interactive communication, interpersonal skills, personal and social responsibility, technology literacy, relevant, high-quality products, basic and visual literacy, curiosity, creativity, and risk-taking. Similarly, Thang, S. and Mahmud, N. $(2017,20)$ confirm that DST is effective in infusing 21st century skills among students. These skills include; language learning skills, information, communication and technology literacy skills, inventive thinking and problem solving skills.

In their experimental study, Rahimi, M. and Yadollahi, S. $(2017,10)$ investigated the effects of offline vs. online digital storytelling on the development of EFL learners' literacy skills (reading and writing). They found out that Reading and writing were mainly promoted through digital storytelling especially with working collaboratively using an online platform. Additionally, Gimeno-Sanz, A. $(2015,116)$ found out that DST effective in developing non-linguistic skills, as well as improving language acquisition for technical university students. Yang, Y. and Wu, W. $(2012,339)$ found that DST participants performed significantly better than lecture-type participants in terms of English achievement, some critical thinking skills (Interpretation and Evaluation of arguments), and learning motivation. Similarly, Razmi, M.; Pourali, S. and Nozad, S. $(2014,1541)$ assure that the use of DST techniques helps students develop better oral skills. In a similar vein, Di Blas, N. and Boretti, B. $(2009,48)$ assert that DST increases students' engagement and their sense of individual responsibility, and involved disabled kids. Miller, E. (2009, pp 12 - 13) outlines the main advantage of Digital Storytelling as it helps to bridge disconnect between the 
high-tech world outside of school and the traditionally low-tech school setting. It provides students with a strong foundation in what are being called "21st Century Skills".

\subsection{Critical Reading:}

According to Kurland, D. (2000), critical reading refers to a careful, active, reflective and analytic reading. For Abu Shihab, E. $(2011,212)$, it is learning to evaluate, draw inferences and find the conclusions based on the evidence. So, according to Hong, M. and Zhiyuan, P. $(2014,78)$, critical readers do not take everything that the writer says in a text for granted. Instead, readers identify the major viewpoints, analyze facts, examples and statistics listed as evidence, get the implied meaning, and evaluate the appropriateness and consistency in reasoning. In Haromi, F. $(2014,128)$ and Wallace, M. and Wray, A. $(2011,29)$ critical reading is the ability to read between the lines in an attempt to find out about the writer's stance, the strategic organization of the text, the nature of the writer's argument and underlying aims and agendas. In the same context, Huijie, L. $(2010,40)$ adds that critical reading analyzes

not only what a text says but also how it is said. Additionally, Dar, Z.; Rahimi, A. and Shams, M. $(2010,458)$ state that in critical reading, text comprehension lies not in the text itself but in the complex interaction between the author's intent and the reader's ability to decode the author's intent.

For Smith, N. and Dechant, E. (1961, 357) and Maltepe, S. (2016, 169), critical reading is the process of evaluating the authenticity and validity of material and of formulating an opinion about it. Similarly, in Watson, G. and Reissner, S. (2014, 58), critical reading is an in-depth way of engaging with written materials that helps you enhance your understanding of the subject and your ability to make informed decisions .Knott, D. (2017, -) states that critical reading is to make judgements about how a text is argued. This is a highly reflective skill requiring you to "stand back" and gain some distance from the text you are reading. You might have to read a text through once to get a basic grasp of content before you launch into an intensive critical reading. 
In the same vein, Maltepe, S. (2016, pp 169 -171) asserts that critical reading refers to individuals' thinking about what they read, assessing what they have read, and using their own judgment about what they have read. So, the critical reader interrogates the writer's assumptions, viewpoints, or purpose. This conforms to Demiroz, H. (2007, 69) who sees that critical reading has a dialogic nature. The critical reader communicates with not only the text but also the author of the text. For Demiroz, a reader comes to the reading task with his/her own agenda, cultural identities, and social roles.

Wheeler, L. (2018) states that critical reading means actually thinking about the subject, moving beyond what the original essay concluded to the point of how the author reached that conclusion and the degree to which that conclusion is accurate. Another broader definition for critical reading is that of Lestari, Z. $(2015,521)$ who asserts that critical readers actively try to discover information and ideas within the text. It is done by analyzing, synthesizing, drawing inference, forming interpretations and evaluating what they read.

\subsection{Rationale for Critical Reading in EFL:}

With the great mass of information and information sources available to students nowadays, it is logical to equip our students with the tools to discern and scrutinize the truthfulness, validity, relevancy and prejudices of these information sources. That is why critical reading has a vital status in reading instruction not only for academic purposes but also for life. It has this status for many reasons; for Mustapha, W. and Paramasivam, Sh. $(2018,330)$ critical reading is essential for students to be successful in their academic pursuit. For Tengberg, M. $(2016,635)$ critical reading is important for a rich involvement in modern social and cultural life and for many concrete reallife decisions. Moreover, the development of critical reading practices reflects a key component in an education for democratic citizenship or as Kaur, S. $(2013,24)$ names it "active and informed citizens". 
In Dar, Z.; Rahimi, A. and Shams, M. $(2010,471)$ critical reading is a means to make learners more empowered language users. Therefore, Asghar, J. (2014, 181) argues that critical reading skills become more challenging as well as crucial for ESL and EFL learners. Similarly, Sharifian, F. and Ghahraki, Sh. $(2005,37)$ assures that critical reading helps readers to understand the purpose or the motivation behind the creation of a text. This is because the writer's purpose directly affects the way the text is constructed.

In Wallace, C. (2003, 189), when students are involved in critical talk while conducting critical readings, they get more than one benefit: they make extensive use of the language of enquiry and judgement; they comment meta-cognitively on their own opinion forming and reflection and finally the students refer directly to the value of having opinions and of being able to articulate them effectively. That is why Sidhu, G. et al $(2015,43)$ confirms that critical reading skills are often viewed as a fundamental pillar for postgraduate study. Similarly, for Alqatanani, A. (2017, 310) critical reading skills help in being competent in the technological revolution. According to Anstey, A. and Bull, G. $(2006,37)$ without the ability to read critically, students can be marginalized, discriminated against, or be unable to take an active and informed place in life. That is reason Thomas, K. $(2018,322)$ states that critical reading should be the chief focus in higher education courses as it prepares adults for the workforce.

Abd Kadir, N. et al $(2014,209)$ argued that if students acquired critical reading skills, they would perform well in any subject/course because they have developed the critical reading skills to not only understand but analyze any text given to them. This will also help them to score better in any tests or exams. In the same line, Lestari, Z. $(2015,520)$ assured that critical reading is particularly important in this era as advanced societies are changing from industrial to informational societies. So, the search, selection, application of information, and the creation of knowledge play an important role in both individual and social development. Abu Shihab. E. $(2011,213)$ 
assures that critical reading involves the use of news media in the class. Newspapers, magazines, television, and radio can motivate students to develop critical listening and reading skills.

\section{Statement of the Problem:}

Based on the results gained from the pilot study, the researcher made sure that there is deficiency in EFL preparatory students' critical reading skills. This deficiency may be due to insufficiency of these skills in the current curriculum, shortcomings in the currently used teaching methods or lack andlor inappropriateness of teaching aids. So, the researcher intended to try to develop some critical reading skills of preparatory students using the proposed program.

\section{Questions of the Research:}

This research tries to answer this main question:

1 - What is the effectiveness of Digital Storytelling in developing some critical reading skills for EFL preparatory stage students?

Out of this main question, the following sub questions are derived;

a - To what extent is DST effective in developing "Identifying what the title indicates" skill?

$\mathrm{b}$ - To what extent is DST effective in developing "Identifying main ideas "skill?

c - To what extent is DST effective in developing "Identifying facts and opinions" skill?

$\mathrm{d}$ - To what extent is DST effective in developing "Identifying relevant and irrelevant materials" skill?

$\mathrm{e}-$ To what extent is DST effective in developing "Recognizing hidden assumptions" skill?

\section{Hypotheses of the Research:}

1 - There is statistically significant difference at (.05) between mean scores of students' of the experimental group and those of the control group on the posttest of overall critical reading skills in favour of the experimental group. 
2 - There is statistically significant difference at (.05) between mean scores of the pretest and posttest of the experimental group on overall critical reading skills in favour of the posttest.

\section{Delimitations of the Research:}

\section{This research is limited to;}

1 - Some critical reading skills; Identifying what the title indicates, identifying main ideas, identifying facts and opinions, identifying relevant and irrelevant materials, and recognizing hidden assumptions.

2 - A sample of (70) first year preparatory stage students from Kamshish Prep School, Tala Educational Directorate, Menoufia, Egypt.

3 - A Two-month period for the experimental treatment during the first semester of the scholastic year 2017 - 2018.

\section{Design of the Research}

The present research adopted the quasi-experimental design to investigate the effectiveness of the proposed Digital Storytelling program in developing the critical reading skills of the research participants. Figure (4) illustrates the quasi-experimental design of the research.

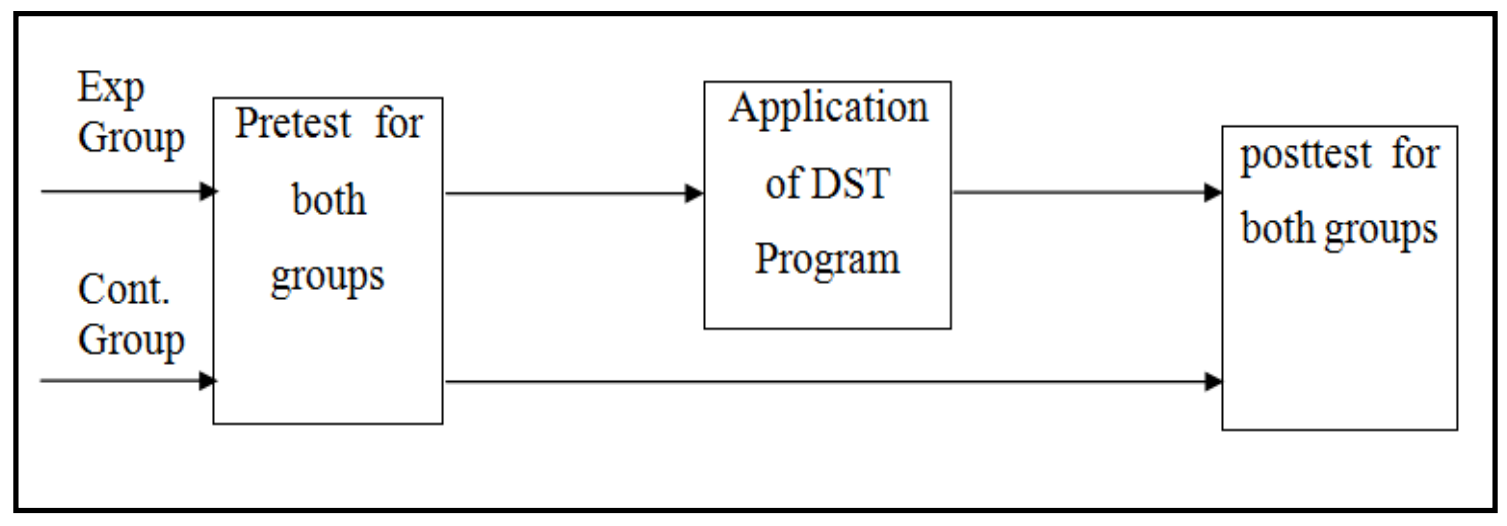

Fig (2): The Flowchart of the Research Design 


\section{Variables of the Research:}

A - The independent variable of the research is a program based on English Storytelling.

B - The dependent variable of the research is some Critical Reading skills.

\section{Instrument of the Research:}

For the purpose of the research, the following instrument was designed and used by the researcher:

1. A Critical Reading Pre-Post Test for assessing students' EFL critical reading skills which are:

1 - Identifying what the title indicates.

2 - Identifying main ideas.

3 - Identifying facts and opinions.

4 - Identifying relevant and irrelevant materials.

5 - Recognizing hidden assumptions.

Following is a description of the steps the researcher went through to design the current program:

\section{Procedures of the Research:}

In order to verify the research hypotheses, these procedures are going to be followed:

1 - Reviewing the previous pedagogical literature related to CR and DST.

2 - Preparing a list of CR skills included in the first year preparatory curriculum to determine the list of skills to be researched. 
3 - Preparing a list of CR skills and subskills, submitting it to a panel of specialists, modifying it upon their remarks \& recommendations and determining the skills to be researched in the study.

4 - Preparing CR pre/ post test in the light of the list of CR skills.

5 - Validating the CR test by submitting it to a panel of specialists and modifying it upon their remarks \& recommendations then computing the test reliability.

6 - Preparing the DST program \& the Teacher's Guide and submitting them to a panel of specialists to ensure their validity and convenience and modifying it upon their remarks.

7 - Selecting the research sample randomly from the first year preparatory students in Tala schools and dividing them into two groups.

8 - Applying the pretest on both groups and ensuring the Equivalence of the two groups.

9 - Applying the experimental treatment (digital storytelling program) on the experimental group only and using the regular way to teach the control group.

10 - Applying the posttest on both the experimental and control groups.

11 - Analyzing the results statistically.

12 - Interpreting and discussing the study findings.

\section{Results:}

\section{1 Verifying the First Hypothesis}

The first hypothesis of the research was: There is statistically significant difference at (.05) between mean scores of students' of the experimental group and those of the control group on the posttest of overall critical reading skills in favour of the experimental group.

The following table shows results of this hypothesis 
Table (1): T-test of the Experimental Group \& Control Group Posttest

\begin{tabular}{|c|c|c|c|c|c|c|}
\hline \multirow[t]{2}{*}{ CR Skill } & \multicolumn{2}{|c|}{$\begin{array}{c}\text { Control Group } \\
\mathbf{N}=35\end{array}$} & \multicolumn{2}{|c|}{$\begin{array}{c}\text { Experimental } \\
\text { Group } \\
\mathbf{N}=\mathbf{3 5} \\
\end{array}$} & \multirow[t]{2}{*}{$\begin{array}{c}(\mathbf{T}) \\
\text { Value }\end{array}$} & \multirow[t]{2}{*}{$\begin{array}{c}\text { Effect } \\
\text { size }\end{array}$} \\
\hline & Mean & SD & Mean & SD & & \\
\hline $\begin{array}{l}\text { Identifying what } \\
\text { the title indicates }\end{array}$ & 2.8 & 1.70 & 3.37 & 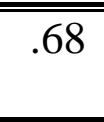 & $3.28^{*}$ & (.79 \\
\hline $\begin{array}{l}\text { Identifying main } \\
\text { ideas }\end{array}$ & 2.97 & .91 & 3.48 & .65 & $2.66^{*}$ & 1.64 \\
\hline $\begin{array}{l}\text { Identifying facts } \\
\text { and opinions }\end{array}$ & 2.69 & 1.06 & 3.14 & 7.54 & $2.21^{* * *}$ & .54 \\
\hline $\begin{array}{l}\text { Identifying } \\
\text { relevant and } \\
\text { irrelevant materials }\end{array}$ & 2.91 & .73 & 3.37 & .64 & $2.76^{*}$ & .67 \\
\hline $\begin{array}{l}\text { Recognizing } \\
\text { hidden } \\
\text { assumptions }\end{array}$ & 2.63 & .59 & 3.14 & .83 & $2.92^{*}$ & .71 \\
\hline Total Test & 14.1 & 1.94 & 16.51 & 1.56 & $5.64^{*}$ & 1.3 \\
\hline
\end{tabular}

Results in the table show that the mean score of the control group students on the posttest of overall critical reading skills is (14.1) with standard deviation of (1.94), while the mean score of experimental group students on the post test of overall critical reading skills is (16.51) with standard deviation of (1.56). The t-test value between the two scores is (5.64), which is much greater than the one tailed table t-test value at (.01) and at a degree of freedom of (68). So, there is a significant difference between the scores of the two groups on the overall critical reading skills at (.01) in favour of the experimental group. The table also shows the effect size value of (1.3) which is a high effect size value. Consequently, the program is considered effective in improving the critical reading skills of the experimental group. 
The following diagram shows the improvement in each of the above mentioned critical reading skill:

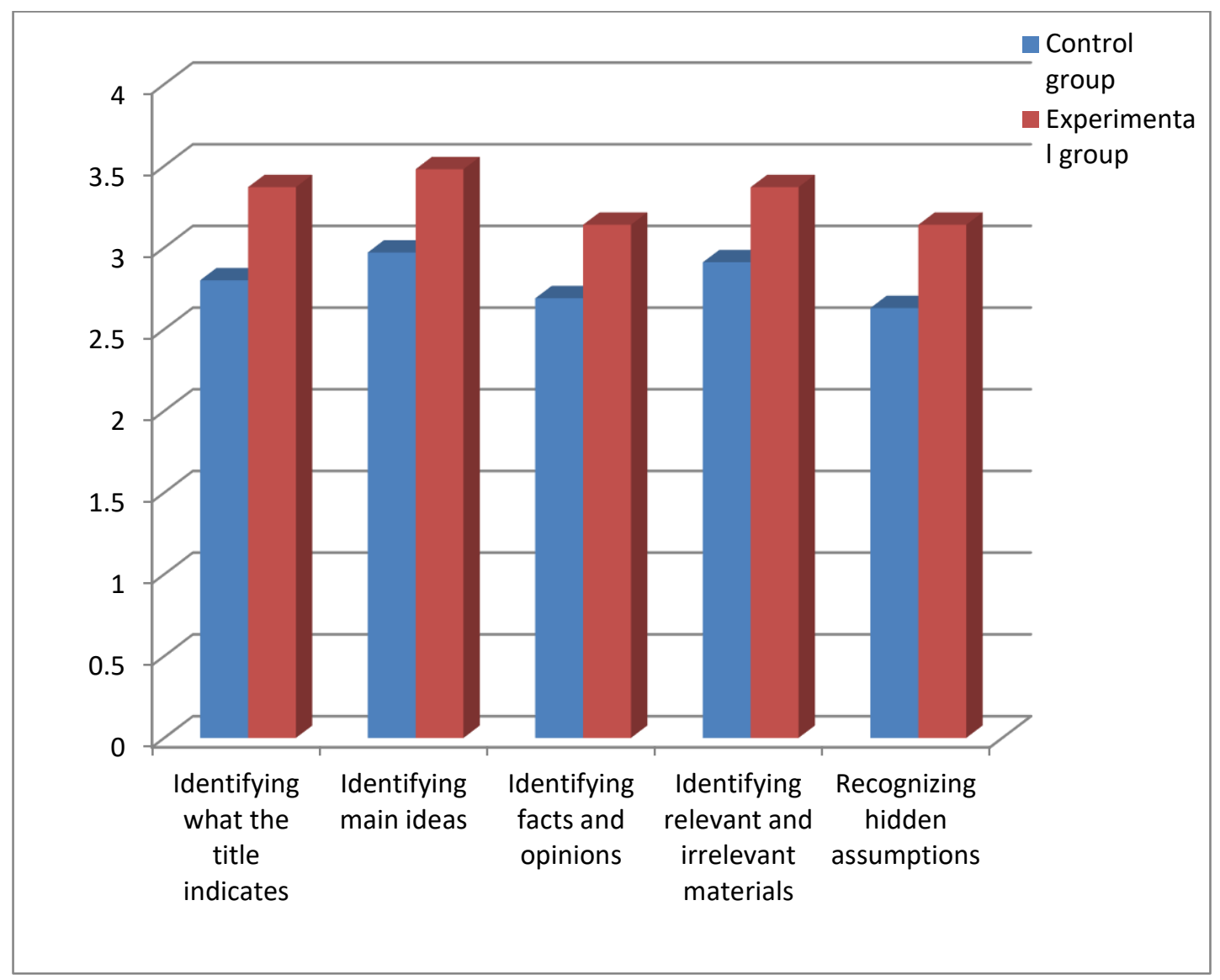

Fig (3): Difference between the Control \& the Experimental Groups' Mean Scores of each Skill on the CR Posttest.

To sum up, the statistical analysis of the results shows that students of the experimental group outperformed the students of the control group on the critical reading posttest on both the overall critical reading skills and each critical reading skill. There is a statistically significant difference at (.01) between mean scores of students of the experimental group and those of the control group on the posttest of overall critical reading skills in favour of the experimental group.

Moreover, there is a statistically significant difference at (.01) between mean scores of students of the experimental group and those of the control group on the posttest of the critical reading skills of "Identifying what the title indicates", "Identifying main 
ideas", "Identifying relevant and irrelevant materials" and "Recognizing hidden assumptions" in favour of the experimental group. And there is a statistically significant difference at (.05) between mean score of students of the experimental group and that of the control group on the posttest of the critical reading skill on "Identifying facts and opinions" in favour of the experimental group.

Difference in performance between the scores of both groups is attributed to the experimental treatment. All the above mentioned means that the first hypothesis is accepted and verified.

\subsection{Verifying the Second Hypothesis}

The second hypothesis of the research was: There is statistically significant difference at (.05) between mean scores of the pretest and posttest of the experimental group on overall critical reading skills in favour of the posttest.

The following table shows results of this hypothesis.

Table (2): T-test of the Experimental Group Pretest \& Posttest

\begin{tabular}{l||c|c||c|c||c||c}
\hline \hline \multirow{2}{*}{ CR Skill } & \multicolumn{2}{c||}{ Pretest } & \multicolumn{2}{c||}{ Posttest } & (T) & Effect \\
\cline { 2 - 6 } & Mean & SD & Mean & SD & Value & Size \\
\hline \hline $\begin{array}{l}\text { Identifying what } \\
\text { the title indicates }\end{array}$ & 2.82 & .91 & 3.37 & .68 & $2.05^{* *}$ & .50 \\
\hline $\begin{array}{l}\text { Identifying main } \\
\text { ideas }\end{array}$ & 2.8 & 1.01 & 3.48 & .65 & $2.24^{* *}$ & .54 \\
\hline \hline $\begin{array}{l}\text { Identifying facts } \\
\text { and opinions }\end{array}$ & 2.91 & .87 & 3.14 & .54 & $1.29-$ & N/A \\
\hline $\begin{array}{l}\text { Identifying } \\
\text { relevant and } \\
\text { irrelevant materials }\end{array}$ & 3.02 & .74 & 3.37 & .64 & $1.74^{* *}$ & .42 \\
\hline \hline $\begin{array}{l}\text { Recognizing } \\
\text { hidden } \\
\text { assumptions }\end{array}$ & 2.77 & .59 & 3.14 & .83 & $1.82^{* *}$ & .44 \\
\hline \hline \multicolumn{1}{c||}{ Total Test } & 14.3 & 2.1 & 16.51 & 1.56 & $2.52^{* *}$ & .61 \\
\hline \hline
\end{tabular}


The previous table shows that the mean score of the experimental group's pretest results of overall critical reading skills is (14.3) with standard deviation of (2.1), while the mean scores of experimental group's posttest result of overall critical reading skills is (16.51) with standard deviation of (1.56). The T-test value between the two scores is (2.52), which is greater than the one tailed table t-test value at (.05) and at a degree of freedom of (34). The table also shows the effect size value of (.61) which is a high effect size value. So, there is a significant difference between the scores of the two applications on the overall critical reading skills at (.05) in favour of the post application. Consequently, the program is considered effective in improving the critical reading skills of the experimental group.

The following figure shows the improvement in each of the above mentioned critical reading skill:

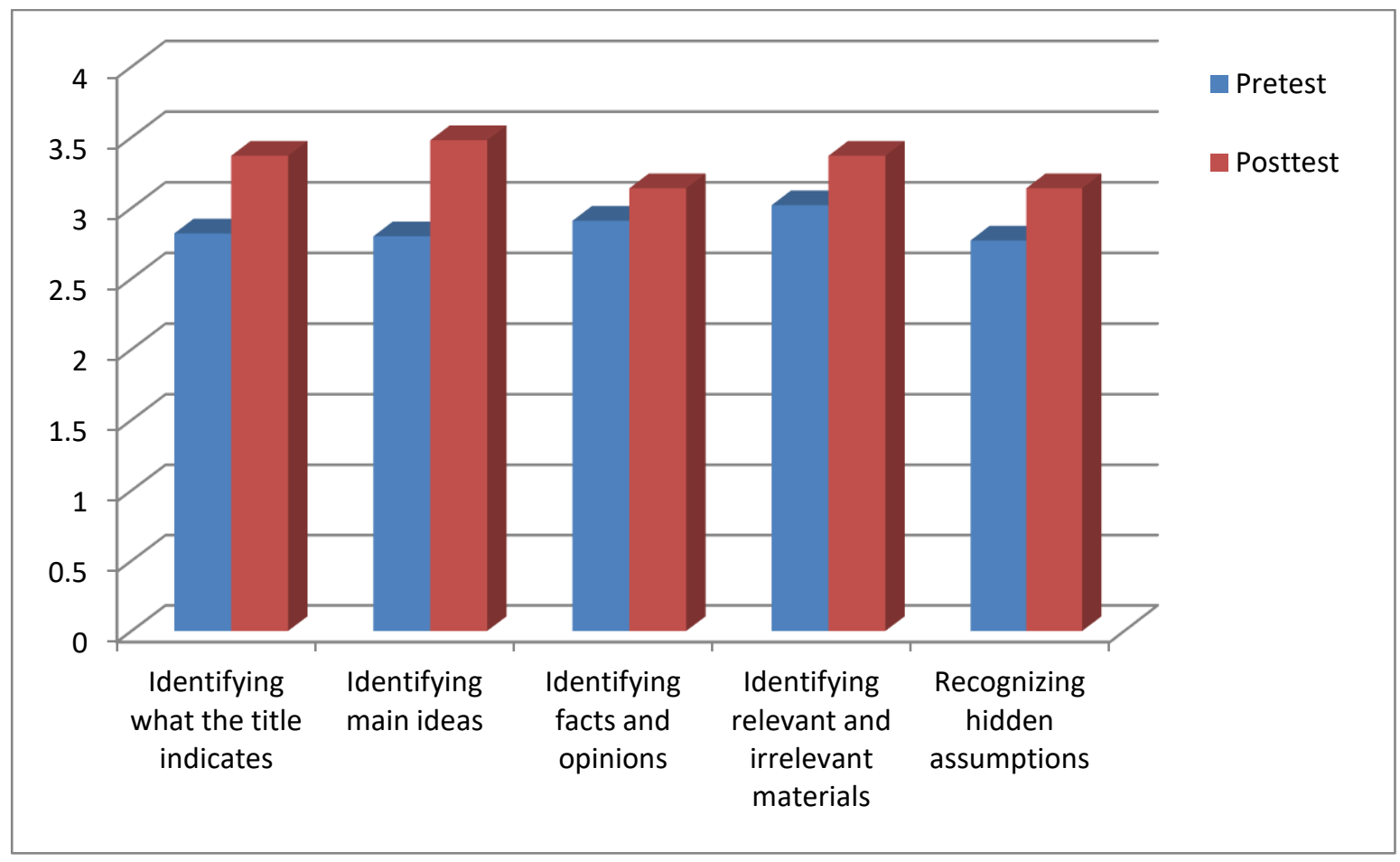

Fig (4): Difference between the Pretest \& Posttest of Experimental Groups' Mean Scores of each Skill. 
Briefly speaking, the statistical analysis of results shows that students' performance on overall critical reading skills on the posttest of critical reading skills has increased after experimental application. Additionally, students' performance of the four skills of "Identifying what the title indicates", "Identifying main ideas", "Identifying relevant and irrelevant materials" and "Recognizing hidden assumptions" have significantly developed. There is a statistically significant difference at (.05) between mean scores of students of the experimental group's pre and post tests of overall critical reading skills in favour of the posttest.

Moreover, there is a statistically significant difference at (.05) between mean scores of the experimental group's pretest and posttest on the critical reading skills of "Identifying what the title indicates", "Identifying main ideas", "Identifying relevant and irrelevant materials" and "Recognizing hidden assumptions", however, the difference in performance concerning the skill of "Identifying facts and opinions "is not statistically significant.

Difference in performance between the scores of two applications is attributed to the experimental treatment. This means that the second hypothesis is accepted and verified.

\section{Recommendations}

Based on the findings of the present research, the following recommendations seem pertinent:

1 - Students should be engaged in reading tasks which enable them to read independently and critically in English.

2 - Teachers should assign class activities to help students read more often applying critical reading skills.

3 - School administrations should encourage critical reading activities in addition to supplying students with necessary tools and equipment to make and share DSTs. 
4 - Curriculum planners and developers are invited to enrich curricula with activities which enhance students' critical reading and make use of DST.

5 - Teacher's Guide should contain a checklist of the necessary EFL critical reading skills and activities so that teachers can foster them.

6 - Teachers have to encourage students to work together as much as possible, through group work and pair work as it is important to share ideas with others.

6 - Ministry of Education and English supervisors should encourage teachers implement DST in their classes by arranging training courses for teachers in DST and other uses of modern technology so as to utilize them in instruction.

7 - Teachers should select activities related to students' personal experiences and previous knowledge; the thing which DST provides.

8 - Teachers are asked to help students to be self-managed, discerning learners who identify problems, judge text content and use active learning strategies in order to increase their critical thinking and critical reading ability.

9 - Teachers should make use of modern technology; particularly DSTs to make reading tasks more amiable and free of tension and risks. 


\section{References}

- Abd Kadir, N. et al (2014). The Importance of Teaching Critical in a Malaysian Reading Classroom. Research paper, the 2014 WEI International Academic Conference Proceedings, Bali, Indonesia

- AbdulAal, Sh. (2016). Utilizing an integrated language instruction based program to enhance critical reading and communicative competence among EFL secondary school students. Unpublished PhD dissertation, Faculty of Education, Zagazig University.

- Abu Shihab. E. ( 2011) .Reading as Critical Thinking. Asian Social Science, Volume 7(8), $209-218$

- Akin, F. ; Koray, O. and Tavukçu, K. (2015). How effective is critical reading in the understanding of scientific texts?. Procedia - Social and Behavioral Sciences 174 ( 2015 ) $2444-2451$

- Allam, M.(2014). The Effect of a Program Based on Using Blended Learning on Developing Critical Reading Skills of EFL Secondary. Unpublished MA thesis, Faculty of Education, Ain Shams University.

- Alqatanani, A. (2017). Do Multiple Intelligences Improve EFL Students' Critical Reading Skills? Arab World English Journal (AWEJ) Volume.8 (1), pp 309- 321

- Asghar , J. (2014). Teaching of Critical Reading Skills in ESL and EFL Context: A Proposal for Action Researchers. Arab World English Journal, AWEJ Volume.5 (1), pp 180 - 196

- Bedeer, F. (2017). The Effect of A Brain - Based Learning Program on Developing Primary Stage Students' English Language Critical Reading Skills. Unpublished PhD dissertation. Faculty of Education, Ain Shams University.

- Dar, Z. ; Rahimi, A. and Shams, M. (2010). Teaching Reading with a Critical Attitude: Using Critical Discourse Analysis (CDA) to Raise EFL University Students' Critical Language Awareness (CLA). International Journal of Criminology and Sociological Theory, Volume 3 (2), 457-476

- Di Blas, N. and Boretti, B. (2009). Interactive storytelling in pre-school: a case-study. Proceedings of IDC 2009, ACM, NY (2009), pp. 44-51.

- Egyptian Ministry of Education (2012). The National Curriculum Framework for English as a Foreign Language (EFL) Grades 1-12. Available at : http://moe.gov.eg/ccimd/pdf/21ummari_quality1.pdf

- El-lehleh, S. (2011). The Effectiveness of Self-questioning Strategy in Developing the Critical Reading Skills Among First Year Secondary Stage Students. Unpublished MA Thesis, Faculty of Education, Minoufia University.

- El Morsi, M.(2015). The Effect of Mind Maps on Developing Some Creative Reading Skills in English for the Second Year Experimental Preparatory School Pupils. Unpublished MA thesis, Faculty of Education, Helwan University. 
- El-Sakka, S. (2011). A Proposed Program Based On Blending Process Writing Approach With Web Logs To Develop The Writing Performance And Critical Reading Of EFL Prospective Teachers. Unpublished PhD Dissertation, Faculty of Education, Suez Canal University, Suez Branch.

- Gimeno-Sanz, A. (2015). Digital storytelling as an innovative element in English for Specific Purposes. Procedia - Social and Behavioral Sciences, Volume 178 , pp 110 116

- Haromi, F. (2014). Teaching through Appraisal: Developing Critical Reading in Iranian EFL Learners. Procedia - Social and Behavioral Sciences 98, 127 - 136

- Hokanson, B.; Clinton, G. and Kaminski, K. (2018). Educational Technology and Narrative: Story and Instructional Design. Springer International Publishing AG, Switzerland.

- Hong, M. and Zhiyuan, P. (2014). Is Critical Reading Indispensible to College English for General Purpose in China? Cross-Cultural Communication, volume 10 (3), pp 77-83.

- Huijie, L. (2010). Developing a Hierarchical Framework of Critical Reading Proficiency. Chinese Journal of Applied Linguistics, Volume 33 (6), 40 - 54

- Hung, C.-M., Hwang, G.-J., \& Huang, I. (2012). A Project-based Digital Storytelling Approach for Improving Students' Learning Motivation, Problem-Solving Competence and Learning Achievement. Educational Technology \& Society, 15 (4), 368-379.

- Hussain, H. and Shiratuddin, N. (2015). Usage of Digital Storytelling for Media Creation on Tablet, Aust. J. Basic \& Appl. Sci., 9(18), pp 41-47

- Kaur, S. (2013). Critical Literacy Practices of English Major in a Tertiary Institution. GEMA Online ${ }^{\circledR}$ Journal of Language Studies, Volume 13(2),21 - 39

- Knott, D. (2017). Critical Reading Towards Critical Writing. New College Writing Centre, University of Toronto. Available at http://advice.writing.utoronto.ca/researching/critical-reading. [Retrieved on 16-12 2017]

- Kurland, D. (2000). How the language really works: The fundamentals of critical reading and effective writing-critical reading v. critical thinking. Retrieved from : http://www.criticalreading.com/critical reading thinking.htm

- Lestari, Z. (2015). The Teaching of Critical Reading in an EFL Classroom.

- Lisenbee, P. and Ford, C. (2018). Engaging Students in Traditional and Digital Storytelling to Make Connections Between Pedagogy and Children's Experiences. Early

Childhood Educ J, Volume 46, pp 129-139

- LoBello, Ch. (2015). The Impact of Digital Storytelling on Fourth Grade

Students' Motivation to Write, Education and Human Development Master's Theses, Paper 573.

- Makhyoun, W. (2008). The Effectiveness Of Story Mapping Journal Writing Strategy In Developing Some Critical Reading Skills Among Prospective Teachers at the Faculty Of Education. Unpublished MA Thesis, Faculty of Eduacation, Alexandria University, Damanhour Branch. 
- Maltepe, S. (2016). An analysis of the critical reading levels of pre-service Turkish and literature teachers. Eurasian Journal of Educational Research, Issue 63, 169-184.

- Marone, F. (2017). Engaging in the Classroom: Learning and Teaching through Digital Stories. Proceedings 2017, Volume 1(9), pp 971 - 978

- McLaughlin, M. and DeVoogd, G. (2004). Critical literacy as comprehension: Expanding reader response. Journal of Adolescent \& Adult Literacy, Vol 48(1), 52-62.

- Medina, S. (2012). Effects of Strategy Instruction in an EFL Reading Comprehension Course: A Case Study. PROFILE, Volume 14 (1), pp 79-89

- Minakova, L. (2014). Critical Thinking Development in Foreign Language Teaching for Non-language-majoring Students, Procedia - Social and Behavioral Sciences 154 ( 2014 ) $324-328$.

- Mohammed, A. (2017). Utilizing a Reflective Learning Model to Develop Creative Reading, Responses to the Virtual World of Literature, and its Relation to Text Readability of the EFL Language Secondary School Students. Unpublished PhD dissertation, Faculty of Education, Zagazig University.

- Mohamed, M. (2012). Using Inference Skills to Develop Some Critical Reading Skills of EFL Prospective Teachers. Unpublished MA Thesis, Suez Canal University.

- Mohamed, R. (2002). The Effectiveness of Using First Year Secondary students' Questions in Developing Their Critical Reading Skills in the Light of Schema Theory. Unpublished MA thesis, Faculty of Women, Ain Shams University.

- Mustapha, W. and Paramasivam, Sh. (2018). Propagating Critical Reading and Creative Writing Literacy Using Reader's Digest Magazines. Proceedings of the 1st Annual International Conference on Language and Literature, 18-19 April 2018, Fakultas Sastra, UISU, Medan, Indonesia.

- Normann, A. (2011). Digital Storytelling in Second Language Learning, master thesis, Norwegian University of Science and Technology.

- Ohler, J. (2013). Digital Storytelling in the Classroom: New Media Pathways to literacy, learning and creativity ( $2^{\text {nd }}$ ed.). Corwin Press.

- Paul, R. and Elder, L. (2014). Critical Thinking: Tools for Taking Charge of Your Professional and Personal Life (2 ${ }^{\text {nd }}$ ed.). Pearson Education Inc.

- Prensky, M. (2008). The Role of Technology in teaching and the classroom, Educational Technology, Nov-Dec 2008

- Rahimi, M. and Yadollahi, S. (2017). Effects of offline vs. online digital storytelling on the development of EFL learners' literacy skills. Cogent Education. Available at http://www.tandfonline.com/doi/pdf/10.1080/2331186X.2017.1285531

- Razmi, M.; Pourali, S. and Nozad, S. (2014). Digital Storytelling in EFL Classroom (Oral Presentation of the Story): A Pathway to Improve Oral Production. Procedia - Social and Behavioral Sciences Volume 98, pp1541 - 1544

- Robin, B. (2005). The Educational Uses of Digital Storytelling. University of Houston, USA.

- Robin, B. (2016). The Power of Digital Storytelling to Support Teaching and Learning. Digital Education Review, n 30, pp 17-29 
- Sharda, N. (2010). Towards Advancing e-Learning through Digital Storytelling. Retrieved on 4-2-2018 from https://www.academia.edu/672750/Towards_Advancing_eLearning_through_Digital_Storytelling

- Sidhu, G. et al (2015). Assessment for Learning Within and Beyond the Classroom. Taylor's $8^{\text {th }}$ Teaching and Learning Conference 2015 Proceedings.

- Smeda, N. (2014).Creating Constructivist Learning Environments with Digital Storytelling. A PhD dissertation, College of Engineering and Science, Victoria University.

- Standley, M. (2003). Digital Storytelling: using new technology and the power of stories to help our students learn and teach. Available at https://msu.edu/ nienhou5/DigitalStorytellingSIG/Benefits_files/Mark\%20Standley.p df

- Strategic Plan of Pre-college Education 2014 - 2030 (2014): Ministry of Education, Egypt.

- Tamim, T. et al (2011). A multi-year investigation of the relationship between pedagogy, computer use and course effectiveness in postsecondary education. J Comput High Educ, volume 23, 1-14

- Thang, S. and Mahmud, N. (2017). Digital Storytelling and its Contributions to Development of workplace Skills in Southeast-Asian Context. Journal of Institutional Research in South East Asia - Volume 15(1), pp 20 - 40

- URL: http://w3techs.com/technologies/overview/content language/all. retrieved on 20 - 12 $-2017$

- Wallace, M. and Wray, A. (2011). Critical Reading and Writing for Postgraduates ( $2^{\text {nd }}$ ed.). SAGE Publications Ltd, London

-Wheeler, L. (2018). Critical Reading of An Essay's Argument. Retrieved from : http://web.cn.edu/kwheeler/reading_basic.html

- Xu, Y., Park, H., \& Baek, Y. (2011). A New Approach Toward Digital Storytelling: An Activity Focused on Writing Selfefficacy in a Virtual Learning Environment, Educational Technology \& Society, 14 (4), 181-191.

- Yang, Y. and Wu, W. (2012). Digital storytelling for enhancing student academic achievement, critical thinking, and learning motivation: A year-long experimental study. Computers \& Education, volume 59 (2), 339-352

- Zaki, E et al (2014). The Effect of using Electronic mind mapping on developing First Secondary Stage Student's EFL Critical Reading Skills. Available at https://search.mandumah.com/Record/720858.

- Zin, Z., Eng, W. and Rafik-Galea, Sh. (2014). Critical Reading Ability and its Relation to L2 Proficiency of Malaysian ESL Learners. The Southeast Asian Journal of English Language Studies - Vol 20(2): 43 - 54 